\title{
A New Species, New Synonymy and a New Record of Eriophyoid Mites (Acari: Eriophyidae), From Egypt
}

\author{
Elhalawany, A. S. \\ Fruit Trees Mites Dept., Plant Protection Research Institute, ARC, Dokki, Giza, Egypt, dr_ashraf_said@yahoo.com.
}

\begin{abstract}
A new eriophyoid mite species, Heterotergum zaheri sp. nov. from Ziziphus spina-christi (L.) Desf (Rhamnaceae) is described and illustrated. This mite is vagrant in the tender apical shoots (between hairs) and on the lower surface of young leaves. It causes no apparent damage. In addition, a supplementary description of Vittacus bougainvilleae (Keifer, 1959) comb. nov. (transferred from Phyllocoptes), is provided; it is recorded for the first time in Egypt, infesting Bougainvillea glabra Choisy (Nyctaginaceae). Moreover, Aculops guajavae Abou-Awad, Al-Azzazy \& Afia, 2016, which causes rust on terminal leaves of Psidium guajava L. (Myrtaceae), is set as a junior synonym of Tegolophus guavae (Boczek, 1960) and redescribed.
\end{abstract}

Key words: Eriophyidae, Heterotergum, Vittacus, Bougainvillea, Ziziphus, Guava, taxonomy.

\section{INTRODUCTION}

Ziziphus spina-Christi (L.) Desf. (Rhamnaceae), is an evergreen tree which is native to northern, tropical Africa as well as southern and western Asia where it is more commonly known as Christi thorn or Christ's Thorn Jujube (Dafni et al., 2005). Bougainvilleas are climbing ornamental plants that can be used to decorate walls, fences, gates and hedges.

To date more than 94 species have been reported from the family Eriophyoidae in Egypt. The Phytoptidae has only three species, the Eriophyidae has 89 species, and the Diptilomiopidae has two species (Zaher, 1984; Elhalawany, 2012, 2017; Elhalawany \& El_Adl, 2017 and Elhalawany\& Ueckermann, 2015 \& 2018).

The genus Heterotergum was established by Keifer (1955), based on Heterotergum gossypii Keifer which causes bronzing of mature cotton leaves, Gossypium hirsutum L. (Malvaceae) in Brazil. The main character of the genus Heterotergum shows a few dorsal annuli behind the prodorsal shield that are equally narrow, followed by a series of broad dorsal annuli which become narrower towards the rear (Amrine et al., 2003).

Until now, twelve Heterotergum species were known to occur in the world according to (de Lillo and Amrine, personal communication) among them, only Heterotergum flacourtiae Abou-Awad and Nasr, 1983 was described from Egypt (Table 1). Thirteen eriophyoid species belonging to other genera have been recorded from the plant genus Ziziphus until now, none of them has been found in Egypt (Amrine et al., 2003 and Salari et al., 2018). Only one species of eriophyid mite was recorded on Ziziphus from Egypt, Aceria mauritianae Amrine \& Stasny, 1994 (=Aceria ziziphi Mohanasundaram, 1990) on Ziziphus mauritiana Lam. reported by Elhalawany, 2012.
The genus Vittacus was established by Keifer (1969) based on the type species Vittacus mansoni Keifer and characterized by body fusiform; gnathosoma projecting obliquely down; dorsal opisthosoma flat with transverse thickened bands; opisthosoma typically divided into broad dorsal annuli, and narrow microtuberculate ventral annuli. So far, ten species of the genus Vittacus are known worldwide, among them only one species was previously recorded from Egypt, Vittacus plucheae Abou-Awad \& Nasr, 1986 on Pluchea dioscoridis L. (Guo et al., 2015).

The bougainvillea rust mite, Phyllocoptes bougainvilleae Keifer, 1959 was discovered in Florida and California by Ochoa \& Amrine, 1998 (unpublished, Amrine personal communication, 2018). Originally described from Brazil, this rust mite was discovered in Kenya and re-described as Vittacus bougainvilleae by Abou-Awad \& El-Banhawy 1991 (Navia et al., 2010). After careful study by Prof. Amrine \& Ron Ochoa, comparing specimens from Egypt (sent by the author) with paratypes of Keifer's material, prepared several different ways, the mite was determined to belong in Vittacus, not Phyllocoptes. Fresh material, cleared in modified Berlese medium at about $95^{\circ} \mathrm{C}$ for 3-4 hours always resulted in specimens with characters that matched $P$. bougainvilleae Keifer, 1959; overheated slides produced specimens with obvious characters of $V$. bougainvilleae. But, reconsideration of the characters of this mite places it in Vittacus, not in Phyllocoptes (Amrine personal communication).

Finally, I compared the characters of Tegolophus guavae (Boczek, 1960) with Aculops guajavae AbouAwad, Al-Azzazy \& Afia, 2016 from Psidium guajava L. (Myrtaceae) in Egypt, A. guajavae AbouAwad et al. is recognized as a junior synonym of Tegolophus guavae (Boczek, 1960).

In this paper, a new species of Heterotergum is described and illustrated. In addition, eriophyid mites 
Table 1. Heterotergum mite species worldwide and their type host, habits and type locality

\begin{tabular}{|c|c|c|c|}
\hline Species & Type host & Habits & type locality \\
\hline Heterotergum gossypii Keifer, 1955 & Gossypium hirsutum L. (Malvaceae) & bronze the mature leaves & Brazil \\
\hline Heterotergum wilsoni Keifer, 1956 & $\begin{array}{l}\text { Simmondsia chinensis (Link) Schneid. } \\
\text { (Simmondsiaceae) }\end{array}$ & vagrant among leaf hairs & (California) USA \\
\hline Heterotergum tuttlei Keifer, 1961 & Trixis californica Kellogg (Asteraceae) & vagrant among leaf hairs & (Arizona) USA \\
\hline Heterotergum olneyae Keifer, 1963 & Olneya tesota Gray (Fabaceae) & $\begin{array}{l}\text { inhabit tomentum of green } \\
\text { stems and on lower surface } \\
\text { of leaves }\end{array}$ & (Arizona) USA \\
\hline Heterotergum yumensis Keifer, 1966 & Acacia greggi Gray (Fabaceae) & leaf and twig vagrant & (Arizona) USA \\
\hline $\begin{array}{llll}\text { Heterotergum } & \text { schlingeri } & \text { Wilson } \& \\
\text { Oldfield, } 1966 & & & \end{array}$ & $\begin{array}{l}\text { Ambrosia chenopodifolia (Benth.) Payne } \\
\text { (Asteraceae) }\end{array}$ & $\begin{array}{l}\text { probably inquiline in galls } \\
\text { of Aceria franseriae }\end{array}$ & (Sonora) Mexico \\
\hline $\begin{array}{ll}\text { Heterotergum } & \text { shevtchenkoi } \\
\text { Bagdasarian, } 1972 & \end{array}$ & Pistacia atlantica Desf. (Anacardiaceae) & $\begin{array}{l}\text { vagrant on lower leaf } \\
\text { surface }\end{array}$ & Armenia \\
\hline Heterotergum zexmeniae Keifer, 1973 & $\begin{array}{l}\text { Wedelia texana (A. Gray) B.L. Turner. } \\
\text { (Asteraceae) }\end{array}$ & vagrant. & $\begin{array}{l}\text { (Estado do Jalisco) } \\
\text { Mexico }\end{array}$ \\
\hline $\begin{array}{l}\text { Heterotergum flacourtiae Abou-Awad } \\
\text { \& Nasr, } 1983\end{array}$ & Flacourtia indica Merr. (Flacourtiaceae) & vagrant & Giza region, Egypt. \\
\hline $\begin{array}{l}\text { Heterotergum artemisiae Hong \& } \\
\text { Kuang, } 1989\end{array}$ & $\begin{array}{ll}\begin{array}{l}\text { Artemisia } \\
\text { (Asteraceae) }\end{array} & \text { lavandulaefolia } \\
\end{array}$ & vagrant & (Hubei) China \\
\hline Heterotergum crispae Meyer, 1992. & Euclea crispa (Thunb.) (Ebenaceae) & vagrant & (Transvaal) South Africa \\
\hline Heterotergum munduleae Meyer, 1992. & Mundulea sericea (Willd.) (Fabaceae) & $\begin{array}{l}\text { on new growth and new } \\
\text { pods }\end{array}$ & (Transvaal) South Africa \\
\hline
\end{tabular}

infesting Bougainvillea from Egypt are redescribed as Vittacus bougainvilleae (Keifer, 1959) Aculops guajavae Abou-Awad, Al-Azzazy \& Afia, 2016 is redescribed and illustrated as Tegolophus guavae (Boczek, 1960) from Psidium guajava L..

\section{MATERIALS AND METHODS}

During period from September 2012 to 2017, plant samples were collected from Qalyubia and Giza governorates. Eriophyoid mites were collected from the plant samples by direct examination with the aid of a stereo-microscope and mounted on microscope slides in Keifer's F-medium (Amrine and Manson 1996). The specimens were examined under a phase contrast microscope (BX46, Olympus). Illustrations were elaborated with the use of drawing tube attached to the phase contrast microscope and using the Adobe Illustrator ${ }^{\circledR}$ CS6 program. Identification to genus level was conducted using a published key to the world genera of the Eriophyoidea (Amrine et al., 2003). Morphological terminology is based on Lindquist (1996) and data measurements follow (Amrine and Manson 1996; de Lillo et al., 2010). All measurements were made using the software computer program (compu Eye) (Baker, 2005) and are given in micrometres $(\mu \mathrm{m})$ and the number of measured specimens (n) is given within parentheses in the description. For males and immature stages, only the ranges are given. For scanning electron microscope (SEM) images, mites were collected from the laboratory culture, using a fine paint brush 00 from leaf pieces under a dissecting microscope. About 50 individuals of eriophyid mites were placed on aluminum stubs for examination under low vacuum scanning electron microscope (JEOL/EO -
JSM-5200). Live specimens were concentrated to a pellet and affixed to stubs using double-sided sticky tape then sputter-coated with gold-palladium. SEM microscopy was performed at Cairo University, Egypt. They were transferred to the low vacuum chamber of the electron microscope, then examined and photographed.

Holotype and some paratypes are deposited in Fruit Acarology Department, PPRI, ARC, Egypt. While the paratypes are deposited in Arthropod/Mite Collection of the Department of Entomology, Nanjing Agricultural University, Jiangsu Province, China (curator: Dr Xiao-Feng Xue). Two paratypes of each species is deposited at Plant Protection Research Institute collection. Two paratypes of each species is deposited at the Collection of the Department of Zoology and Nematology, Faculty of Agricultural, Cairo University, Egypt. Two paratype slides of each species is deposited in the Department of Soil, Plant and Food Sciences (Di.S.S.P.A.), section of Entomology and Zoology, University of Bari Aldo Moro, Bari, Italy (curator: de Lillo). In addition, two paratype slide of each species is deposited in the College of Agriculture and Forestry West Virginia University USA (curator: Amrine).

\section{RESULTS AND DISCUSSION}

Family: Eriophyidae Nalepa, 1898.

Sub family: Phyllocoptinae Nalepa, 1892

Tribe: Anthocoptini Newkrik and Keifer, 1975.

Genus: Heterotergum Keifer, 1955.

Heterotergum zaheri sp. nov. (Fig. 1)

Description:

FEMALE: ( $\mathrm{n}=10)$ body fusiform, 185 (175-190) 
long, 42 (36-45) wide, 45 (43-48) thick; light yellow. Gnathosoma 20 (19-21) long, projecting obliquely downwards, basal setae (ep) 3 (3-4), antapical setae (d) 4 (3-4), chelicerae 18 (16-19) long. Prodorsal shield 27 (26-28) long, 29 (27-31) wide; sub-triangular with short anterior lobe over gnathosoma, rounded, acuminate, 5 (5-7) long; prodorsal shield ornamentation with dashes laterally, incomplete median line on posterior $2 / 3$ of prodorsal shield, two admedian lines complete, connected just ahead of rear margin with slight curved line inwardly on inner side of tubercles $s c$, submedian lines connected with admedian line at $1 / 3$ and $2 / 3$ of shield. Scapular tubercles on rear shield margin, 19 (17-20) apart, setae (sc) 30 (27-31), directed backwards. Coxigenital area with distinct granules and dashes, prosternal apodeme present 5 (5-6); anterolateral setae on coxisternum I (1b) 8 (8-9), 9 (8-10) apart; proximal setae on coxisternum I (1a) 18 (17-19), 9 (8-9) apart; proximal setae on coxisternum II (2a) 33 (30-35), 19 (18-20) apart. Leg I 30 (26-31), femora 8 (7-8), basiventral femoral setae $(b v) 11(10$ 12); genua 6 (5-6), antaxial genual setae $\left(l^{\prime \prime}\right)$ 20 (19-21); tibiae 6 (5-6), paraxial tibial setae $(l)$ 5 (4-5), setae located $1 / 3$ from dorsal base; tarsi 5 (4-5); empodia (em) simple 6 (5-6), 6-rayed, tarsi solenidia $(\omega)$ slightly knobbed, 6 (6-7), paraxial fastigial tarsal setae $\left(f t^{\prime}\right) 13(11-13)$, antaxial fastigial tarsal setae $\left(f t^{\prime \prime}\right) 20$ (17-21), setae $\left(u^{\prime}\right) 3(3-4)$. Leg II 25 (23-26), femora 8 (7-8), basiventral femoral setae $(b v) 10(10-12)$; genua $4(4-5)$, antaxial genual setae $\left(l^{\prime \prime}\right) 9$ (8-11); tibiae $4(4-5)$; tarsi 5 (5-6); tarsal empodia (em) simple 5 (5-6), 6-rayed, tarsal solenidia $(\omega)$ slightly knobbed $8(7-8)$, setae ( $\left.f t^{\prime}\right) 11$ (10-12), setae ( $\left.f t^{\prime \prime}\right) 18$ (17-20), setae (u) 3 (3-4). Opisthosoma 22 (20-22) dorsal annuli, with about 14 broad dorsal annuli, proceeded by 3-4 narrow dorsal annuli directly behind prodorsal shield, elongated microtubercles placed on posterior annuli; broad dorsal annuli with faint elongated microtubercles. Ventral annuli comprise 68 (66-73) annuli (counted from first annulus after coxae II), microtubercles oval, placed on posterior ventral annuli. Lateral setae (c2) 45 (45-47), 18 (16-20) apart, on annulus 9 (9-10) from coxae II; ventral setae I (d) 34 (30-35), 35 (33-38) apart, on annulus 23 (22-24); ventral setae II (e) 10 (8-11), 20 (17-22) apart, on annulus 43 (40-44); ventral setae III $(f) 18$ (17-20), 10 (10-12) apart, on annulus $62(60-65)$ or $6^{\text {th }}$ annulus from rear. Setae (h2) 45 (42-50), 9 (8-9) apart; setae (hl) 3 (2-3). Internal genitalia anterior apodeme with normal 12 (11-12), 20 (18-21) wide, coverflap with 12 (12-14) longitudinal ridges, proximal setae on coxisternum III (3a), 25 (20-26), 14 (12-14) apart.

MALE. $(\mathrm{n}=4)$. Similar to female. Body fusiform, 155 (150-160), 42 (42-45) wide, 37 (35-40) thick;

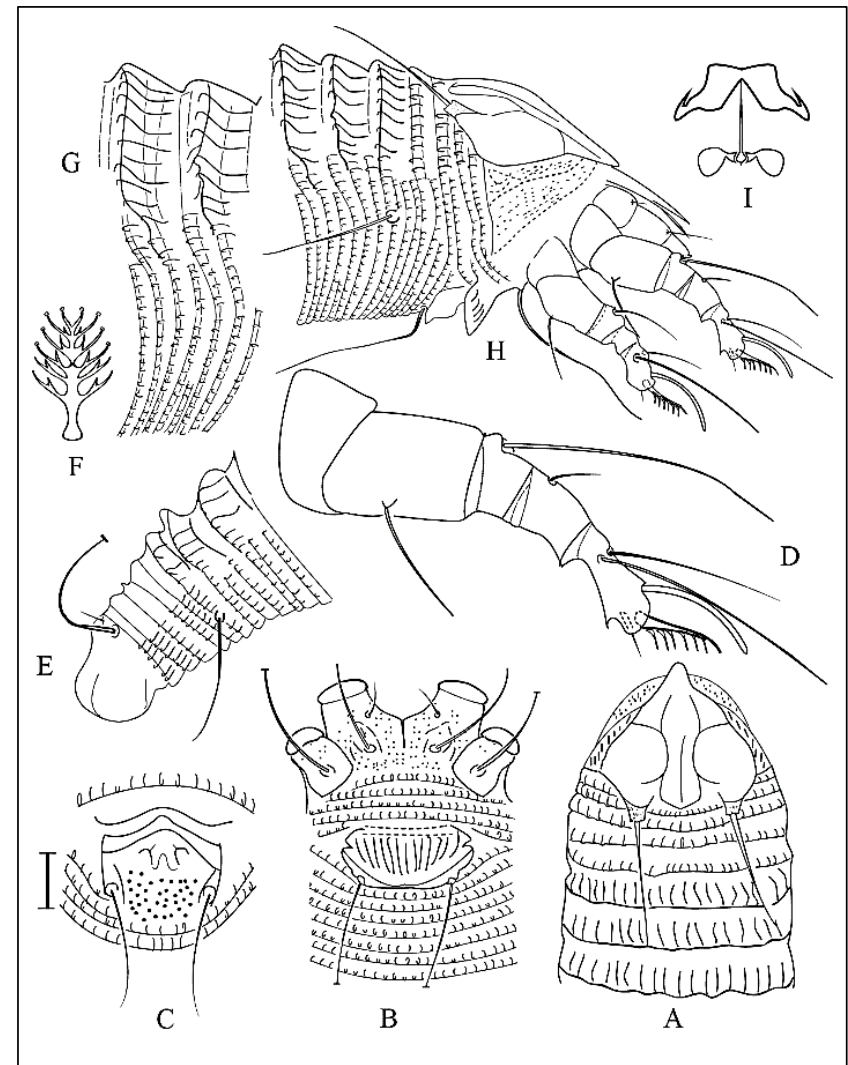

Fig. (1): Line drawings of Heterotergum zaheri sp. nov.: A- prodorsal shield; B- female coxigenital region; C- genital region of male; D- Legs I; E- lateral view of posterior opisthosoma; F- empodium; G- lateral view of annuli; $\mathrm{H}$ - anterior lateral view of mite; I- internal genital of female. Scale bars: $10 \mu \mathrm{m}$ for A, B, C, H, I; $5 \mu \mathrm{m}$ for $\mathrm{D}$ and $2.5 \mu \mathrm{m}$ for $\mathrm{F}$.

light yellow. Gnathosoma 19 (19-20), chelicerae 17 (16-17), setae (ep) 3 (3-4), setae (d) 4 (3-4). Prodorsal shield 26 (26-28), 25 (22-27) wide, ornamentation same as female. Scapular tubercles on rear shield margin, 18 (17-19) apart with setae (sc) 27 (25-28), directed backwards. Ornamentation of coxae same as female: setae (1b) 5 (5-6), 9 (8-10) apart; setae (1a) 15 (14-17), 7 (7-9) apart; setae (2a) 25 (24-26), 16 (16-18) apart. Leg I 25 (23-26), femur 7 (7-8), setae (bv) 10 (10-12); genua $5(4-5)$, setae $\left(l^{\prime \prime}\right) 20$ (19-21); tibiae $6(5-6)$, setae $\left(l^{\prime}\right) 5(4-5)$; tarsi 5 (4-5); tarsal empodia (em) simple 6 (5-6), 6rayed, tarsal solenidia $(\omega)$ distally slight knobbed 6 (6-7), setae $\left(f t^{\prime}\right) 13(11-13)$, antaxial, fastigial, tarsal setae $\left(f t^{\prime \prime}\right) 20$ (17-21), tarsal setae $\left(u^{\prime}\right) 3$ (3-4). Leg II 23 (20-24), femur $6(6-7),(b v) 10(10-12)$; genua 4 (3-4), (l') 9 (8-11); tibiae 4 (4-5); tarsi 5 (5-6); ( em) simple 5 (5-6), 6-rayed, solenidia ( $\omega) 8(7-8),\left(f t^{\prime}\right)$ 11 (10-12), (ft') 18 (17-20), (u') 3 (3-4). Opisthosoma with 22 (20-22) dorsal annuli, about 14 broad dorsal annuli, proceeded by 3-4 annuli behind prodorsal shield. Ventral annuli 66 (65-70). Microtubercles same as female. Lateral setae (c2) 43 (41-45) apart 18 (16-18), on annulus 9 (9-10) 
(counted from first annulus after coxae II); setae $(d)$ 32 (30-33), 33 (33-35) apart, on annulus 22 (19-22); setae $(e) 10$ (8-11), 20 (17-22) apart, on annulus 39 (39-42); setae (f) 15 (15-18), $10(10-11)$ apart, on $6^{\text {th }}$ annulus from rear. Setae (h2) 42 (42-50), 8 (8-9) apart; setae $(h l) 3$ (2-3). External genitalia $9(8-10)$, 18 (17-18) wide, with granules, proximal setae on coxisternum III (3a) 18 (18-20), 15(14-15) apart.

Host plant. Ziziphus spina-christi (L.) Desf. (Rhamnaceae).

Relation to the host plant. Vagrant in the tender apical shoots between hairs and on lower surface of young leaves, causing no apparent damage.

Type Locality. Shebeen Al-Qanater region, Qalyubia Governorate, Egypt, 30¹8'19.01"N, 31 $18^{\circ} 8.66 " E, 15$ September 2013 and 26 September 2015 coll. Ashraf S. Elhalawany.

Type material. Holotype, single female on a microscope slide (slide no. EGP-Erio18.1), deposited at Fruit Trees Mites Dept., Collection, Plant Protection Research Institute (PPRI), Dokki, Egypt. Paratypes, 30 females and 10 males on 30 separate microscope slides deposited at Fruit Trees Mites Dept., Collection, Plant Protection Research Institute (PPRI), Dokki, Egypt. Two slides at Plant Protection Research Institute collection. Four females and one male (slide number: NJAUAcariEriEgypt32.1-32.5), deposited as slide mounted specimens in the Arthropod/Mite Collection of the Department of Entomology, Nanjing Agricultural University, Jiangsu Province, China; Two paratypes slide mounts are also deposited in the Department of Soil, Plant and Food Sciences (Di.S.S.P.A.), section of Entomology and Zoology, University of Bari Aldo Moro, Bari, Italy. Two paratypes slides is deposited at Plant Protection Research Institute collection. Two paratypes slide is deposited in the College of Agriculture and Forestry West Virginia University USA.

Etymology. This species is named after the Emeritus Prof. Dr. Mohammed Abdel-Aziz Zaher, Department of Zoology and Nematology, Agri. Cairo Univ., Egypt.

Differential diagnosis. The new species herein described was compared with all Heterotergum species and no similarities among any of them were observed. A few similarities were observed with Heterotergum yumensis Keifer 1966 collected from Acacia greggi Gray (Fabaceae).The new species differs from $H$. yumensis in shape and rays number of empodial rays (6-rayed compared to H. yumensis which bears 7-rays), prodorsal shield pattern (the new species shows a pattern of distinctive lines versus a series of granules appear to form lines in $H$. yumensis), number of dorsal semiannuli (14 in the new species versus 18 in $H$. yumensis), number of ventral semiannuli (68 with oval microtubercles in the new species versus 53 with round and bead-like microtubercles in $H$. yumensis). The new species differs from Heterotergum flacourtiae Abou-Awad and Nasr 1983 collected from Flacourtia indica Merr., by prodorsal shield pattern (presence of sub-median lines in the new species versus absent in $H$. flacourtiae, and number of dorsal and ventral semiannuli (14 and 68 in the new species versus 10 and 59 annului in $H$. flacourtiae).

Genus Vittacus Keifer, 1969, C2: 13-14.

Vittacus bougainvilleae (Keifer, 1959) comb. nov. (Figs 2-5)

Synonyms

Phyllocoptes bougainvilleae Keifer, 1959, 28(2): 910, Fig. 7.

Vittacus bougainvilleae Abou-Awad \& ElBanhawy, 1991:331-332.

Phyllocoptes bougainvilleae Keifer, 1959; Navia et al., 2010: 236.

\section{Redescription:}

FEMALE: $(\mathrm{n}=15)$ body fusiform, 180 (178-185) long, 60 (57-60) wide, 52 (52-57) thick; light yellow. Gnathosoma 22 (21-23) long, projecting obliquely downwards, basal setae (ep) absent, antapical setae (d) 4 (4-5), chelicerae 16 (14-16) long. Prodorsal shield 38 (37-39) long including frontal lobe, 44 (43-45) wide; prodorsal shield frontal lobe over gnathosoma, rounded, acuminate, 6 (5-6) long; Prodorsal shield ornamentation network, median and admedian lines complete, sinuate, forming four cells with cross lines on each side of median line, two submedian lines diverging from anterior lobe ending at $1 / 2$, the outer submedian line meeting in inwardly curves back just inside the dorsal tubercles, forming elongate cells laterally on prodorsal shield and some granules on lateral lobe. Scapular tubercles near the rear shield margin, 22 (20-22) apart, setae (sc) 22 (20-24), projecting up and diverging. Coxigenital area with few curved lines and granules, prosternal apodeme present $6(5-6)$; anterolateral setae on coxisternum I ( $1 b) 6$ (6-7), 12 (10-12) apart; proximal setae on coxisternum I (1a) 16 (16-18), 8 (7-8) apart; proximal setae on coxisternum II (2a) 31 (29-32), 20 (20-21) apart. Leg I 32 (30-35), femur 9 (9-10), basiventral femoral setae $(b v)$ 12 (11-13); genu5 (5-6), antaxial genual setae $\left(l^{\prime \prime}\right)$ 25 (24-27); tibiae 7 (7-8), paraxial tibial setae $\left(l^{\prime}\right)$ 5 (4-5), setae located 1/4 from dorsal base; tarsi 7 (6-7); empodia (em) simple 5 (4-5), 3-rayed, tarsi solenidia $(\omega)$ slightly knobbed, 7 (6-7), paraxial fastigial tarsal setae $\left(f t^{\prime}\right) 13(12-14)$, antaxial fastigial tarsal setae $\left(f t^{\prime \prime}\right) 21(18-21)$, setae $\left(u^{\prime}\right)$ absent. Leg II 30 (28-31), femur 9 (8-9), basiventral femoral 


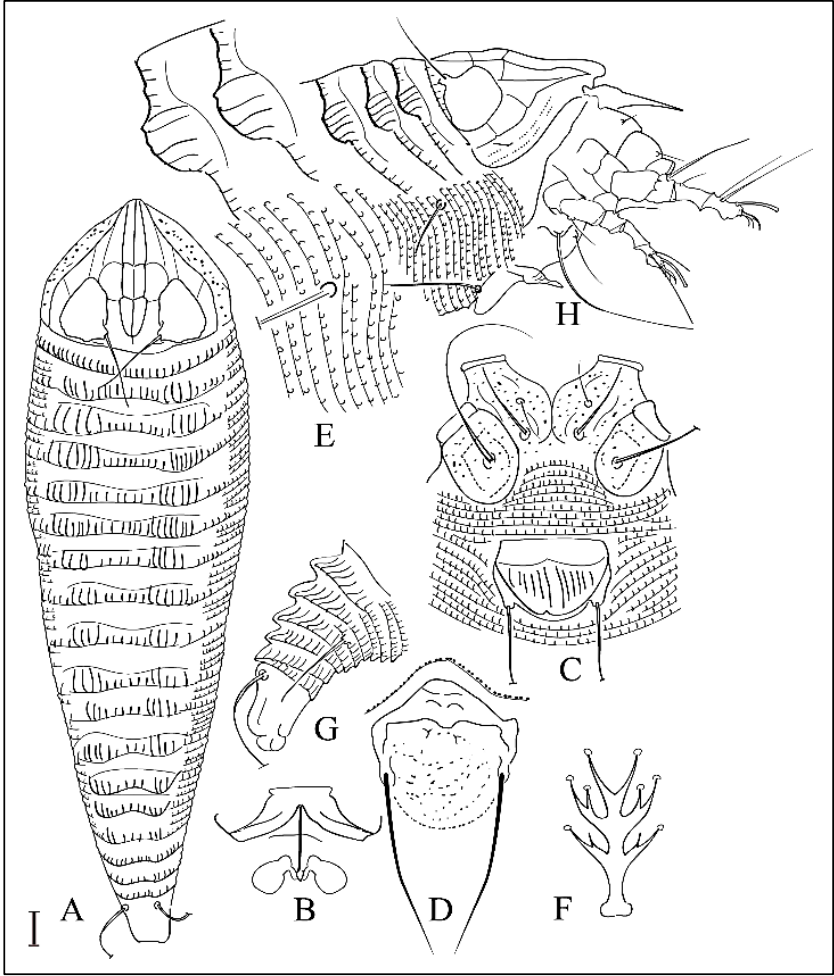

Fig. (2): Line drawings of Vittacus bougainvilleae (Keifer) comb. nov.: A-dorsal view of female; Binternal female genitalia; $\mathrm{C}$ - female coxigenital region; $\mathrm{D}$ - male genitalia; $\mathrm{E}$ - lateral view of annuli; F- empodium; G- lateral view of posterior opisthosoma; $\mathrm{H}$. anterior lateral view of mite. Scale bars: $10 \mu \mathrm{m}$ for A, G, H; $5 \mu \mathrm{m}$ for B,C, D; $2.5 \mu \mathrm{m}$ for $\mathrm{F}$.
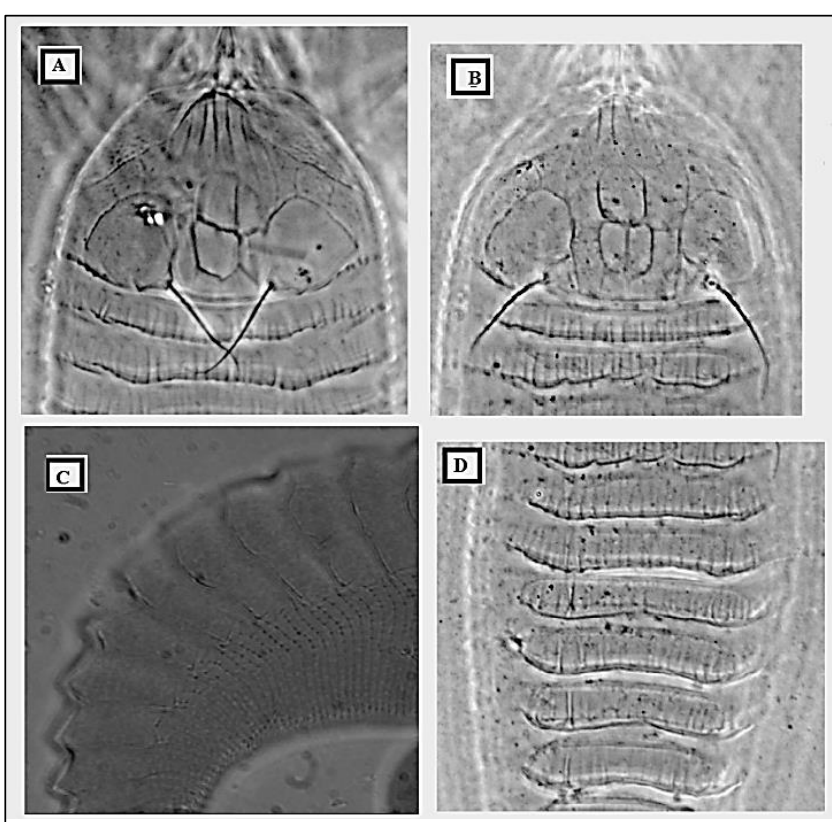

Fig. (4): Phase microphotograph of Vittacus bougainvilleae (Keifer) comb. nov.: $\mathrm{A}$ and $\mathrm{B}$ Dorsal view of mite; C- Coxigenital female; DCoxigenital male.

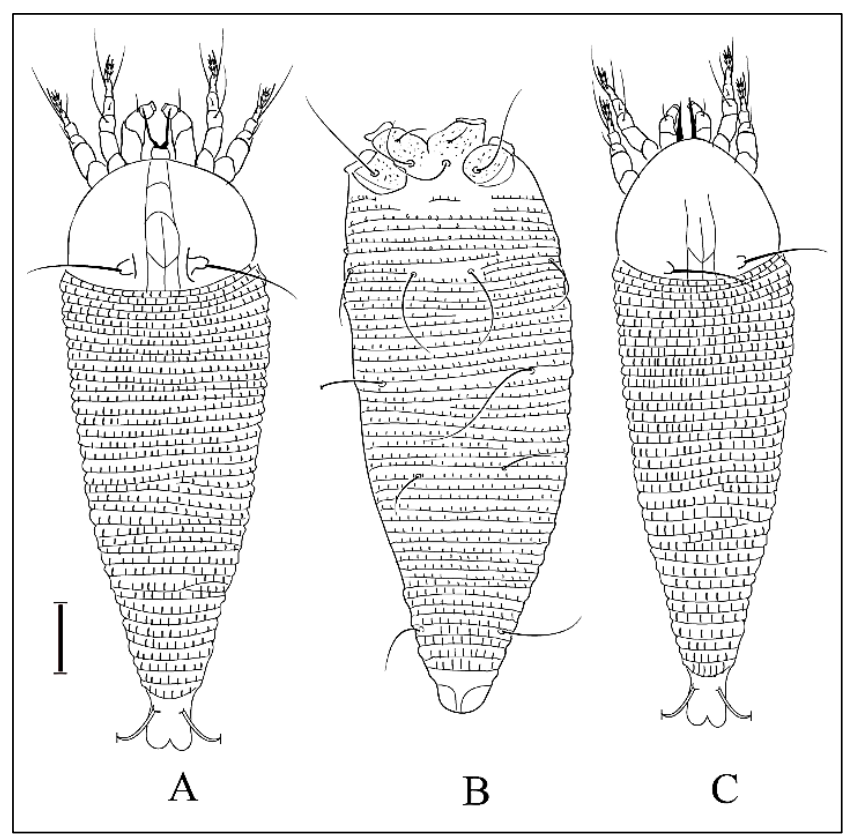

Fig. (3): Line drawings of Vittacus bougainvilleae (Keifer) comb. nov.: A- dorsal view of nymph; B- ventral view of nymph; C- dorsal view of larva. Scale bars: $10 \mu \mathrm{m}$.

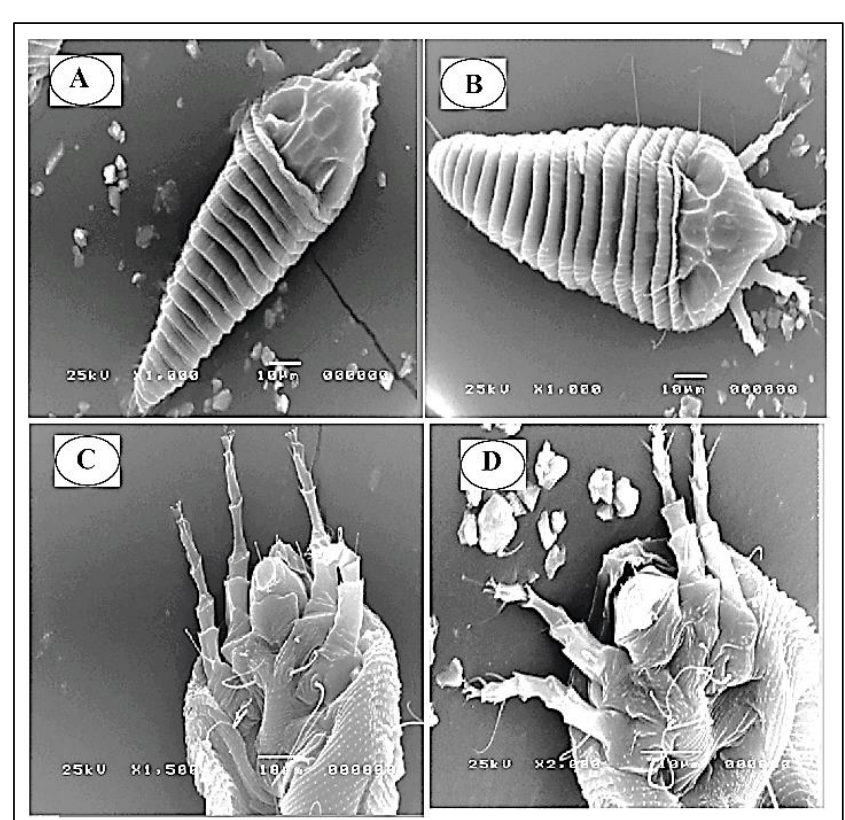

Fig. (5): SEM photograph of Vittacus bougainvilleae

(Keifer) comb. nov.: A and B Dorsal view of mite; C- Coxigenital female; D- Coxigenital male. 
setae (bv) 12 (11-13); genu 5 (4-5), antaxial genual setae $\left(l^{\prime \prime}\right) 7(7-8)$; tibiae $6(6-7)$; tarsi $6(6-7)$; tarsal empodia (em) simple 5 (5-6), 3-rayed, tarsal solenidia $(\omega)$ slightly knobbed 6 (6-7), setae $\left(f t^{\prime}\right) 9$ (710), setae $\left(f t^{\prime \prime}\right) 23(21-24)$, setae $\left(u^{\prime}\right)$ absent. Opisthosoma18 (18-19) dorsal annuli, broad dorsal annuli with elongated liner microtubercles; ventral annuli with 64 (62-66) annuli (counted from first annulus after coxae II), microtubercles rounded elongate, placed on posterior ventral annuli, on the last 10 annuli, the ventral microtubercles are linear. Lateral setae (c2) 14 (12-15), 54 (54-55) apart, on annulus 13 (11-14) from coxae II; ventral setae I $(d)$ 48 (45-52), 36 (35-37) apart, on annulus 23 (22-26); ventral setae II (e) 17 (15-17), 21 (20-21) apart, on annulus 37 (37-40); ventral setae III ( $f$ ) 25 (24-27), $14(14-15)$ apart, on annulus $58(58-62)$ or $5^{\text {th }}$ annulus from rear. Setae $(h 2) 55$ (50-60), 8 (8-9) apart; setae $(h l)$ absent. External genitalia $16(16-$ 17), 20 (20-21) wide, coverflap with 12 (11-12) longitudinal ridges in a single row, proximal setae on coxisternum III (3a), 32 (27-32), 17 (16-17) apart.

MALE. ( $\mathrm{n}=4)$. Similar to female. Body fusiform, 160-173 long, 52-55 wide, 44-48 thick; light yellow. Gnathosoma 21-22, projecting obliquely downwards, chelicerae 15-16, setae (ep)absent, setae (d) 3-5. Prodorsal shield 37-38 long including frontal lobe, $42-45$ wide; prodorsal shield frontal lobe over gnathosoma, rounded, acuminate, 5-6 long; scapular tubercles near the rear shield margin, 20-21 apart, setae $(s c)$ 20-21, projecting up and diverging. Coxigenital area with short curved lines, prosternal apodeme present 5-6; setae (1b) 5-6, 10-11 apart; setae (1a) 13-15, 6-7 apart; setae (2a) 25-30, 19-20 apart. Leg I $28-30$, femora 7-8, setae (bv) 10-12; genua 4-5, setae $\left(l^{\prime \prime}\right)$ 19-22; tibiae 7-8, setae $\left(l^{\prime}\right) 4$ 5; tarsi 5-7; tarsal empodia (em) simple 4-5, 3-rayed, tarsal solenidia $(\omega)$ distally slight knobbed $6-7$, setae $\left(f t^{\prime}\right)$ 11-13, antaxial, fastigial, tarsal setae $\left(f t^{\prime \prime}\right) 18-22$, tarsal setae $\left(u^{\prime}\right)$ absent.

Leg II 26-28, femur 6-8, (bv) 10-12; genua 3-4, $\left(l^{\prime \prime}\right)$ 6-8; tibiae 5-6; tarsi 5-6; empodia (em) simple 4-5, 3-rayed, $(\omega)$ distally slight knobbed $6-7,\left(f t^{\prime}\right) 8-10$, $\left(f t^{\prime \prime}\right)$ 19-21, $\left(u^{\prime}\right)$ absent. Opisthosoma with $18-19$ broad dorsal annuli, ventral annuli 58-60. Microtubercles same as female. Lateral setae (c2) 1116, 52-55 apart, on annulus 11-13 from coxae II; ventral setae $\mathrm{I}(d)$ 44-49, 33-35 apart, on annulus 2225; ventral setae II (e) 15-18, 19-21 apart, on annulus 37-39; ventral setae III (f) 24-28, 13-15 apart, on annulus $54-56$ or $5^{\text {th }}$ annulus from rear. Setae (h2) 50-55, 7-8 apart; setae (hl) absent. External genitalia $12-13,16-18$ wide, proximal setae on coxisternum III (3a) 22-24, 14-15 apart.

NYMPH $(n=4)$. Body spindleform, 152-170; width 41-43. Gnathosoma.16-17, curved downward, d 3-5, cheliceral stylets 12-13. Prodorsal shield. sub-circular, 32-34, 36-38 wide, with pattern of faint lines, median line at $1 / 2$ from rear, complete admedian line connected at $1 / 4,1 / 2$ and $2 / 3$ by transverse lines forming cells. Tubercles $s c$ ahead of rear shield margin, 16-18 apart; sc 15-16 divergently out. Coxisternal plates. With granules, $1 b 3-5,8-9$ apart; $1 a$ 10-11, 6-7 apart; $2 a$ 18-21, 19-20 apart; $3 a$ 19-21, 8-9 apart. Legs. All usual segments and setae present. Leg I 19-21; femur 7, $b v 4-5$; genu 3-3.5, $l^{\prime \prime}$ 13-15; tibia 4-5, l' 3-4; tarsus 4-5, ft' 8-9, ft' 10-13; $\omega$ 4-5; em 3-4, simple, 3-rayed. Leg II 17-18; femur 6-7, bv 5-6; genu 3, $l^{\prime \prime} 7-10$; tibia 3-4; tarsus 3-4, ft' 6-7, ft" 11-13; solenidion $\omega 4-5$; em 3-4, simple, 3rayed. Opisthosoma. With 38-41 dorsal annuli, with liner elongate microtubercles set on rear margin of annuli, 46-48 ventral annuli with oval microtubercles, elongated on the posterior annuli, 68 coxogenital annuli. Seta $c 26-7,38-40$ apart, on 7$8^{\text {th }}$ ventral annulus; $d 26-28,26-27$ apart, on $16-18^{\text {th }}$ ventral annulus; $e$ 8-10, $14-15$ apart, on $26-27^{\text {th }}$ ventral annulus; $f 14-15,13-15$ apart, on $5^{\text {th }}$ annulus from rear. Seta $h l$ absent; $h 215-19$.

LARVA ( $\mathrm{n}=3)$. Body vermiform, 125-148; width 37-40. Gnathosoma.15-16, curved downward, $d 3-$ 4 , cheliceral stylets $10-11$. Prodorsal shield. subcircular, 28-30, 30-33 wide, with pattern of faint lines, median line at $1 / 2$ from rear, admedian line at $2 / 3$ connected at $1 / 4$ by transverse line forming two cells. Tubercles $s c$ ahead of rear shield margin, 15-16 apart; sc 13-15 divergently out. Coxisternal plates. With granules, $1 b$ 3-4, 8-9 apart; 1a 9-11, 6-7 apart; 2a 18-20, 18-19 apart; 3a 16-18, 8-9 apart. Legs. All usual segments and setae present. Leg I 18-20; femur 6-7, bv 4-5; genu 3-3.5, $l^{\prime \prime} 13-14$; tibia 4-5, $l^{\prime}$ 3 (no range); tarsus 3-4, ft' 8-9, ft" 10-11; $\omega$ 4-5; em 3-4, simple, 3-rayed. Leg II 16-18; femur 6-7, bv 46; genu 3, l" 7-9; tibia 3; tarsus 3-4, ft' 6-7, $f t^{\prime \prime} 10$ 12; solenidion $\omega$ 4-5; em 3-4, simple, 3-rayed. Opisthosoma. With 36-38 dorsal annuli, with linear elongate microtubercles set on rear margin of annuli, 43-46 ventral annuli with oval microtubercles, elongated on the posterior annuli, 6-7 coxogenital annuli. Seta $c 2$ 6-7, 36-38 apart, on $6-7^{\text {th }}$ ventral annulus; $d$ 24-26, $25-26$ apart, on $15-16^{\text {th }}$ ventral annulus; $e$ 6-7, 13-14 apart, on $25-26^{\text {th }}$ ventral annulus; $f 13-14,13-14$ apart, on $5^{\text {th }}$ annulus from rear. Seta $h l$ absent; $h 210-15$.

Type data: Bougainvillea spectabilis Willd. (Nyctaginaceae).

Host plant from Egypt: Bougainvillea glabra Choisy and Bougainvillea luteoalba H. \& K. (Nyctaginaceae).

Relation to the host plant: Leaf edge rolling from the underside (Keifer, 1959).In Egypt it causes leaf edge rolling from the underside and wrinkle flowers. 
Geographic distribution: (Sao Paulo) Brazil; Kenya; (California, Florida) USA.

\section{Material examined}

Ten slides (no. NJAUAcariEriEgypt17) from Bougainvillea glabra Choisy (Nyctaginaceae) Egypt, Qalyubia, 30¹7'38.14N, 31 ${ }^{\circ} 14^{\prime} 51.56 " \mathrm{E}, 15$ August 2012. Coll. A. Elhalawany; deposited as slide mounted specimens in the Arthropod/Mite Collection of the Department of Entomology, Nanjing Agricultural University, Jiangsu Province, China.Two slides, with the same data deposited at Department of Soil, Plant and Food Sciences (Di.S.S.P.A.), section of Entomology and Zoology, University of Bari Aldo Moro, Bari, Italy.Two slides, with the same data deposited at Department of Zoology and Nematology, Faculty of Agricultural, Cairo University, Egypt. Five females and 3males on 6 slides, with the same data (no. EGPErio36.1-36.6), 1June 2015, deposited at Fruit Trees Mites Dept., Plant Protection Research Institute Dokki Egypt. Two slides at Plant Protection Research Institute collection.

\section{Remarks}

This is the first record of occurrence of females and males of $\boldsymbol{V}$. bougainvilleae in Egypt. The holotype female was described by Keifer, 1959 from Brazil. The morphometry of the female appears to match the original description by Keifer, 1959. The principal differences between this species and the descriptions given by Keifer are the size of the specimens now examined is shorter (45-50) long; scapular seta $s c$ short 16 long and seta $3 a$ short 25 long; seta $f 17$ long; the Egyptian specimens are slightly longer than those in Keifer's description; while the lateral seta $c 223$ long from Keifer is longer than Egyptian specimens. After careful study by Prof. Amrine specimens from Egypt (sent by the author) were compared to paratypes of Keifer's material, prepared several different ways. Fresh material, cleared in modified Berlese medium at about $95^{\circ} \mathrm{C}$ for 3-4 hours always resulted in specimens with characters that matched $P$. bougainvilleae Keifer, 1959; overheated slides produced specimens with the characters of $V$. bougainvilleae. But, reconsideration of the characters of this mite places it in Vittacus, not in Phyllocoptes; it thus becomes a senior homonym for $V$. bougainvilleae, same name but a later date for the description. Comparison of descriptions indicate that they are different species. If proven to be separate species, Vittacus bougainvilleae Abou-Awad \& ElBanhawy, 1991 needs a new name (Amrine personal communication). But when mounting many slides from different locality from Egypt and using scanning electron microscope found no differences between the two species, and both names may be conspecific. DNA typing is needed to prove speciation.

\section{Tegolophus guavae (Boczek, 1960) (Figs 6-8) Synonyms \\ Tegonotus guavae Boczek, 1960: 11-14.}

Aculops guavae (Boczek, 1960): Craemer C. 1993.

Tegolophus guavae (Boczek, 1960); Amrine \& Stasny, 1996: 300.

Tegolophus guavae (Boczek, 1960); Elhalawany, 2012:207-209.

Aculops Guajavae Abou-Awad, Al-Azzazy\& Afia, 2016: 108-108.

\section{Redescription.}

FEMALE: $(\mathrm{n}=20)$ body fusiform, $165(155-200)$ long without gnathosoma, 60 (55-62) wide, 52 (4760) thick; light yellow. Gnathosoma 25 (25-27) long, projecting obliquely downwards, basal setae (ep) 3 (2-3), antapical setae (d) 4 (4-5), chelicerae 16 (16-18) long. Prodorsal shield 42 (40-43) long including broad rounded frontal lobe 6(6-8), 47 (4450) wide; subtriangular; prodorsal shield ornamentation with faint incomplete median line, split near center of shield into two lines which do not reach anterior margin forming $U$ shape, surface of shield punctuated. Scapular tubercles on rear shield margin, 33 (31-35) apart, setae (sc) 15 (13-16), projecting posteriorly. Coxigenital area with granules, with 9 (8-9) annuli between coxae and genitalia, prosternal apodeme present 6 (5-7); anterolateral setae on coxisternum I ( $1 b) 5$ (5-6), 10 (10-11) apart; proximal setae on coxisternum I (1a) 13 (11-15), 7 (7-8) apart; proximal setae on coxisternum II (2a) 27 (25-30), 20 (19-22) apart. Leg I 32 (30-33), femur10 (9-11), basiventral femoral setae (bv) 7 (7-9); genua 4 (4-5), antaxial genual setae $\left(l^{\prime \prime}\right) 25$ (22-27); tibiae $6(6-7)$, paraxial tibial setae $(l) 4$ (4-5), setae located $1 / 4$ from dorsal base; tarsi 4 (4-5); empodia (em) simple 4 (4-5), 4-rayed, tarsi solenidia $(\omega)$ slightly knobbed, 6 (5-6), paraxial fastigial tarsal setae $\left(f t^{\prime}\right) 15(12-15)$, antaxial fastigial tarsal setae ( $\left.f t^{\prime \prime}\right) 22$ (18-21). Leg II 29 (28-30), femur $8(7-9)$, setae $(b v) 8$ (7-9); genua 5 (4-5), setae $\left(l^{\prime \prime}\right) 7$ (7-8); tibiae 5 (5-6); tarsi 5 (5-6); tarsal (em) simple 4 (3-5), 4-rayed, ( $\omega)$ slightly knobbed 5 (5-6), setae $\left(f t^{\prime}\right) 8(7-10)$, setae $\left(f t^{\prime \prime}\right) 18(17-20)$. Opisthosoma 30 (29-32) dorsal annuli broad, with faint longitudinal lines, with three longitudinal ridges, middorsal ridge stronger than lateral ridges, fading caudally. Ventral annuli with 65 (64-67) annuli (counted from first annulus after coxae II), microtubercles rounded, placed on posterior ventral annuli, the last $10^{\text {th }}$ ventral microtubercles liner. Lateral setae (c2) 17 (15-20), 47 (46-50) apart, on annulus 11 (11-12) from coxae II; ventral setae I (d) 35 (33-38), 31 (30-33) apart, on annulus 25 (24-27); ventral setae II (e) 14 (12-15), 15 (15-17) apart, on annulus 40 (39-42); ventral setae III $(f) 25$ (23-26), 20 (19-21) apart, on annulus 61 $(60-62)$ or $6^{\text {th }}$ annulus from rear. Setae $(h 2) 60$ (5567), 9 (8-9) apart; setae (hl) absent. External 
genitalia 16 (15-17), 23 (22-25) wide, coverflap with 12-14 longitudinal ridges in a single row, proximal setae on coxisternum III ( $3 a), 10$ (9-12), 13 (12-14) apart.

MALE. ( $\mathrm{n}=5$ ). Similar to female. Body fusiform, 140-165 including gnathosoma, 47-53 wide, 44-48 thick; light yellow. Gnathosoma 22-24, chelicerae 13-15, setae (ep) 3-4, setae (d) 3-5. Prodorsal shield 32-34 long including frontal lobe, (42-45) wide; Scapular tubercles near the rear shield margin, 20 (18-21) apart, setae (sc) 19 (18-20), projecting diagonal posteriorly. Coxigenital area with granules, prosternal apodeme present 5 (5-6); setae (1b) 5 (5-6), 8(8-9) apart; setae (1a) 13 (13-15), 7 (7-8) apart; setae (2a) 25 (25-27), 17 (16-18) apart. Leg I 25-27, femora 7-8, setae $(b v)$ 6-7; genu 4-5, setae $\left(l^{\prime \prime}\right)$ 17-19; tibiae 6-7, setae $\left(l^{\prime}\right)$ 4-5; tarsi 5-6; tarsal empodia (em) simple 4-5, 4-rayed, tarsal solenidia $(\omega)$ distally slight knobbed 5-6, setae $\left(f t^{\prime}\right)$ 11-13, setae ( $\left.f t^{\prime \prime}\right)$ 17-20. Leg II 24-26, femora 6-7, setae (bv) 6-7; genu 3-4, setae ( $\left.l^{\prime \prime}\right)$ 17-19; tibiae 5-6; tarsi 5-6; tarsal empodia (em) simple 4-5, 4-rayed, tarsal solenidia $(\omega)$ distally slight knobbed 5-6, setae $\left(f t^{\prime}\right)$ 5-7, setae $\left(f t^{\prime \prime}\right)$ 16-19. Opisthosoma with 28-30 broad dorsal annuli, ventral annuli 52-56. Microtubercles same as female. Lateral setae (c2) 13-16, 38-40 apart, on annulus 7-8 from coxae II; ventral setae $(d)$ 38-43, 24-26 apart, on annulus 18-20; setae (e) 8-10, 13-14 apart, on annulus

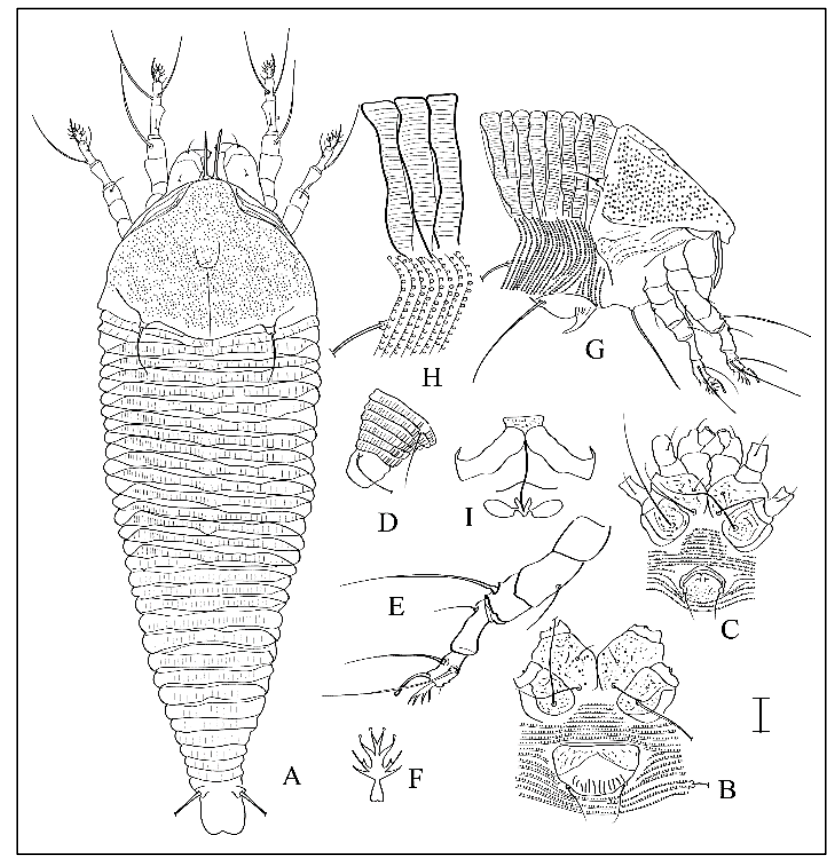

Fig. (6): Line drawings of Tegolophus guavae (Boczek): A-dorsal view of female; B-female coxigenital region; $\mathrm{C}-$ male coxigenital region; D- lateral view of posterior opisthosoma; E-Leg1; $\mathrm{F}$ - empodium; $\mathrm{G}$ - anterior lateral view of mite; $\mathrm{H}$ lateral view of annuli; I- internal genitalia. Scale bars: $10 \mu \mathrm{m}$ for A, B, C, D, G, H; $5 \mu \mathrm{m}$ for E, I; $2.5 \mu \mathrm{m}$ for $\mathrm{F}$.

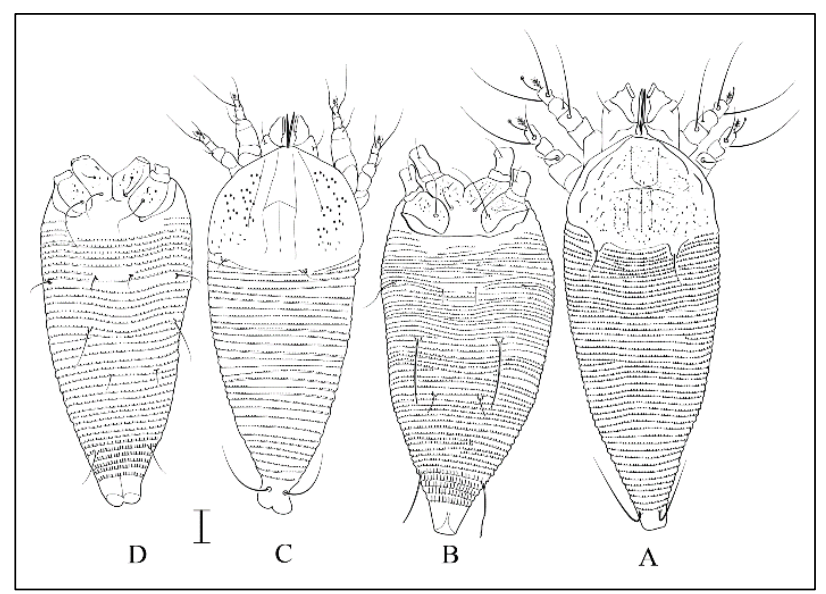

Fig. (7): Line drawings of Tegolophus guavae (Boczek): A- dorsal view of nymph; B- ventral view of nymph; C- dorsal view of larva; Dventral view of larva. Scale bars: $10 \mu \mathrm{m}$.

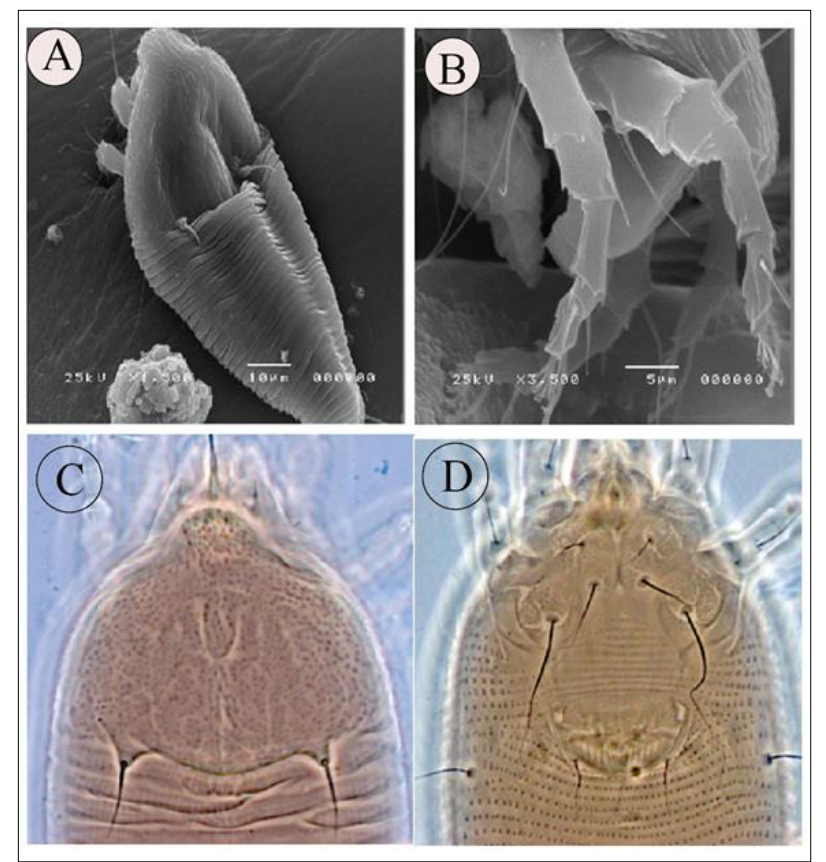

Fig. (8): Tegolophus guavae (Boczek) SEM photograph, A- dorsal view of mite; B- Legs and phase microphotograph C- prodorsal shield; D- Coxigenital female.

$32-35$; setae $(f) 16-19,19-20$ apart, on $6^{\text {th }}$ annulus from rear. Setae ( $h 2) 46$ (42-55); setae $(h l)$ absent.

External genitalia 11-13 long, 13-14 wide, with granules, setae (3a) 8-10, 9-10 apart.

NYMPH $(n=5)$. Body spindleform, 105-122; width 40-46. Gnathosoma.15-16, curved downward, setae d 3-4, cheliceral stylets 12-14. Prodorsal shield. sub-circular, 30-33, 34-37 wide, with pattern of faint lines and granules, median and admedian lines at $1 / 2$ from rear, transverse line at middle, faint $U$ shape from anterior. Tubercles $s c$ on rear shield margin, 2022 apart; sc 10-12 directed backward. Coxisternal plates. With granules, $1 b 3-4,8-9$ apart; $1 a$ 6-8, 6-7 apart; $2 a$ 14-15, 15-16 apart; 3a 3-4, 4-5 apart. Legs. All usual segments and setae present. 
Leg I 21-23; femur 7, $b v$ 4-5; genu 3, $l^{\prime \prime} 11-13$; tibia $4-5, l^{\prime} 2-3$; tarsus 4-5, ft' 10-12, ft" 11-14; $\omega$ 4-5; em 3-4, simple, 3-rayed. Leg II 19-21; femur 6-7, bv 5-6; genu 3, $l^{\prime \prime} 7-8$; tibia 3-4; tarsus 3-4, ft' 6-7, $f^{\prime \prime}$ 11-13; solenidion $\omega 4-5$; em 3-4, simple, 3-rayed. Opisthosoma. With 45-48 dorsal annuli, with pointed oval microtubercles set on rear margin of annuli, 49-53 ventral annuli with pointed oval microtubercles, elongated on the posterior annuli. Seta $c 28-10,38-40$ apart, on $8-9^{\text {th }}$ ventral annulus; $d$ 27-30, 24-26 apart, on 20-21 $1^{\text {th }}$ ventral annulus; e 7-8, 11-12 apart, on 30-32 ${ }^{\text {th }}$ ventral annulus; $f 18-19,16-18$ apart, on $5^{\text {th }}$ annulus from rear. Seta $h 1$ absent; $h 213-18$.

LARVA ( $\mathrm{n}=4)$. Body spindleform, 70-90; width 30-33. Gnathosoma.12-13, curved downward, setae $d$ 3-4, cheliceral stylets 8-10. Prodorsal shield. sub-circular, 23-25, 28-31 wide, with pattern of faint lines and granules, median line at $1 / 2$ from rear, complete admedian lines, connected halfway by transverse line, submedian line from anterior half. Tubercles $s c$ on rear shield margin, 14-16 apart; sc 3-4 directed backward. Coxisternal plates. With granules, $1 b$ 3-4, 9-11 apart; $1 a$ 6-7, 6-7 apart; 2a 11-13, 12-13 apart; $3 a$ 2-3, 4-5 apart. Legs. All usual segments and setae present. Leg I 16-18; femur 5-6, bv 3-4; genu 3, l" 8-10; tibia 3-4, l' 2-3; tarsus 3-4, ft' 8-10, ft" 10-13; $\omega$ 3-4; em 3, 3-rayed. Leg II 14-15; femur 4-5, bv 3-4; genu 3, $l$ " 8-10; tibia 3-4; tarsus 3-4, ft' 5-7, ft" 10-13; $\omega$ 3-4; em 3, 3-rayed. Opisthosoma. With 28-30 dorsal annuli, with pointed oval microtubercles set on rear margin of annuli, 30-33 ventral annuli with pointed oval microtubercles, elongated on the posterior annuli. Seta $c 25-6,22-24$ apart, on 7-8 $8^{\text {th }}$ ventral annulus; $d$ 8-10, 15-16 apart, on $12-13^{\text {th }}$ ventral annulus; $e$ 4-5, 8-9 apart, on $18-19^{\text {th }}$ ventral annulus; $f 10-12$, $10-11$ apart, on $5^{\text {th }}$ annulus from rear. Seta $h l$ absent; h2 $10-15$.

Host plant: Psidium guajava L. (Myrtaceae).

Relation to the host plant: Vagrant on lower and upper surface of leaves causing rust on terminal leaves.

Geographic distribution: Brazil, USA, Egypt.

Material examined: Ten females and 4 males on 10 slides at Qalyubia governorate $\left(30^{\circ} 14^{\prime} 57^{\prime \prime} \mathrm{N}\right.$; $31^{\circ} 17^{\prime} 07^{\prime \prime E}$ ), 6 August 2012, coll. A. Elhalawany. Five females on 3 slides (no. NJAUAcariEriEgypt30) from Psidium guajava L. (Myrtaceae) Egypt, Qalyubia, 30¹4'57"N; 31 ${ }^{\circ} 17^{\prime} 07^{\prime \prime E}, 6$ August 2012. Coll. A. Elhalawany; deposited as slide mounted specimens in the Arthropod/Mite Collection of the Department of Entomology, Nanjing Agricultural University, Jiangsu Province, China. Two slides, with the same data deposited at Department of Soil, Plant and Food Sciences (Di.S.S.P.A.), section of Entomology and Zoology, University of Bari Aldo
Moro, Bari, Italy. Two slides, with the same data deposited at Department of Zoology and Nematology, Faculty of Agricultural, Cairo University, Egypt. Ten females and 3 males on 2 slides, with the same data (no. EGPErio11.1-35.2), 8 May 2015, deposited at Fruit Trees Mites Dept., Protection Research Institute Dokki Egypt. Two slides at Plant Protection Research Institute collection.

New material: Five females, 2 males, 5 nymphs and 10 larvae on 2 slides deposited at Plant Protection Research Institute collection, 5 May 2016, Gharbia governorate. Four females and 2 males on 2 slides of each species is deposited in the College of Agriculture and Forestry West Virginia University USA, 10 November 2017, from Behera governorate, coll. K. Elsayed.

\section{Remarks}

Finally, after comparing the characters of Tegolophus guavae (Boczek, 1960) with Aculops guajavae Abou-Awad, Al-Azzazy \& Afia, 2016 from Psidium guajava L. (Myrtaceae) in Egypt,the author in 2012 recorded T. guavae (Boczek, 1960) for the first time in Qalyubia governorate, and found that $A$. guajavae mite belongs in Tegolophus not Aculops, due to the presence of opisthosoma with 3 ridges on opisthosoma, middorsal ridge stronger than lateral ridges, but fading caudally. While in Aculops opisthosoma dorsally arched without ridges. In addition the pattern of the prodorsal shield matched Boczek's description. Thus, A. guajavae is identical to T. guavae (Boczek, 1960).

\section{REFERENCES}

Abou-Awad, B.A. and El-Banhawy, E.M. 1991. New mites of the family Eriophyidae from Kenia (Acari: Eriophyoidea). Acarologia, 32(4): 329333.

Abou-Awad, B.A. and Nasr, A.K. 1983. Heterotergum flacourtiae n. sp. from Egypt (Acari: Eriophyidae). Int. J. of Acarol., 9(4): 179-181.

Abou-Awad B.A. and Nasr A.K. 1986. An eriophyd mite, Vittacus plucheae sp. n. (Acari: Eriophyoidea: Eriophyidae), on Pluchea dioscoridis L. (Compositae) from Egypt. Acarologia, 27(2): 159-161.

Abou-Awad, B.A.; Al-Azzazy and Afia, S.I. 2016. Biology of Aculops guajavae a new species (Acari: Eriophyidae) infesting guava tree. Int. J. of ChemTech Res., 9(12): 108-113.

Amrine, J.W. and Manson, D.C. 1996. Preparation, mounting and descriptive study oferiophyoid mites. In: Lindquist, E.E., Sabelis, M.W. \& Bruin J. (eds.), Eriophyoid mites: their biology, natural enemies and control. World Crop Pests, 6, Elsevier Science Publishing, Amsterdam, The 
Netherlands, pp. 383-396.

Amrine, J.W. Jr. and Stasny, T.A. 1994. Catalog of the Eriophyoidea (Acarina: Prostigmata) of the world. Indira Publish. House, West Bloomfield, Michigan, USA: 804 pp.

Amrine, J.W. Jr., Stasny, T.A. and Flechtmann, C.H.W. 2003. Revised keys to the world genera of the Eriophyoidea (Acari: Prostigmata). Indira Publishing House, West Bloomfield, Michigan, USA, 244 pp.

Bagdasarian, A.T. 1972. Eriophyid mites on pistachio (Acarina: Eriophyoidea). Doklady. Akad. nauk. Armenian. SSR, 55 (2): 123-128. (In Russian).

Baker, E.M. 2005. A new software for measuring leaf area, and area damaged by Tetranychus urticae Koch. J. Appl. Entomol., 129(3): 173-175.

Boczek, J. 1960: A new genus and three new species of eriophyid mites (Acarina). J. Kans. Entomol. Soc., 33(1): 9-14.

Craemer C. 1993. Eriophyidae (Acari) as potential control agents of South African weeds, with descriptions of a new species of Tegonotus Nalepa. M. Sc. Thesis, Rand Afrikaans University, Johannesburg, South Africa. 162 pp.

Dafni, A., Levy, S. and Lev, E. 2005. The ethnobotany of Christ's Thorn Jujube (Ziziphus spina-christi) in Israel. J. of Ethnobiology and Ethnomedicine.1-8.

de Lillo, E., Craemer, C., Amrine, J.W.Jr. and Nuzzaci, G. 2010. Recommended procedures and techniques for morphological studies of Eriophyoidea (Acari: Prostigmata). Exp. Appl. Acarol., 51, 283-307.

Elhalawany, A.S. 2012. Survey of eriophyid mites on some fruit trees, with re-descriptions of two newly recorded species and a checklist of eriophyid mites in Egypt (Acari: Eriophyoidea). Egypt Acad. J. Biolo. Sci., 5: 205-216.

Elhalawany, A.S. 2017. A new species in the genus Epitrimerus Nalepa (Acari: Eriophyidae) from Lantana camara L. in Egypt. Egypt. Acad. J. Biolog. Sci., 10(7): 149-160. 12 $2^{\text {th }}$ Arab Congress of Plant Protection, ACPP, 4 -10 November, 2017 Hurghada Egypt.

Elhalawany, A.S. and El-Adl, F.E. 2017. A new species and two first records of eriophyoid mite (Trombidiformes: Eriophyoidea: Eriophyidae), From Egypt. Acarines, 11: 1-9.

Elhalawany, A.S. and Ueckermann, E.A. 2015. Four new Aceria species (Acari: Trombidiformes: Eriophyidae) on Acacia nilotica from Egypt. Int. J. Acarol., 41: 272-282.

Elhalawany, A.S. and Ueckermann, E.A. 2018. Three new Aceria species (Acari: Trombidiformes: Eriophyidae) associated with the invasive weed Imperata cylindrica (L.) (Poaceae) from Egypt. Int. J. Acarol., 44:1, 7-20.

Guo, J.F., Sadeghi, H., Gol, A. and Xue, X.F. 2015. A new species of the genus Vittacus Keifer (Acari:
Eriophyidae) from Iran. Persian J. Acarol., 4(1) 57-63.

Hong, X.Y. and Kuang, H.Y. 1989. Three new genera and seven new species of the subfamily Phyllocoptinae (Acari: Eriophyidae) from China. Int. J. Acarol., 15 (3): 145-152.

Keifer, H.H. 1955.Eriophyid Studies XXIII. Bulletin of the California Department of Agriculture, 44, 126-130.

Keifer, H.H. 1956. Eriophyid Studies XXIV. Bulletin of the California Department of Agriculture, 44, 159-164.

Keifer H.H. 1959. Eriophyid Series XXVIII. Occasional Papers. California Department of Agriculture, 2: 1-20.

Keifer, H.H. 1961. Eriophyid Studies B-2, California Department of Agriculture, $20 \mathrm{pp}$.

Keifer, H.H. 1963. Eriophyid Studies B-9, California Department of Agriculture, $20 \mathrm{pp}$.

Keifer, H.H. 1966 Eriophyid Studies B-18, California Department of Agriculture, $20 \mathrm{pp}$.

Keifer, H.H. 1969. Eriophyid studies C-2. U.S. Department of Agriculture, Agricultural Research Service, $24 \mathrm{pp}$.

Keifer, H.H. 1973 Eriophyid Studies C-8. U.S. Department of Agriculture, Agricultural Research Service, $24 \mathrm{pp}$.

Lindquist, E.E. 1996. External anatomy and notation of structures. In: Lindquist, E.E., Sabelis, M.W. \& Bruin, J. (eds.), Eriophyoid Mites: their Biology, Natural Enemies and Control. World Crop Pests, 6, Elsevier Science Publishing, Amsterdam, The Netherlands, pp. 3-31.

Meyer, M.K.P. 1992. African Eriophyoidea: on Heterotergum Keifer, 1955 and a new genus Pyelotus (Acari: Eriophyidae). Phytophylactica, 24 (2): 157-161.

Mohanasundaram, M. 1990. Studies on the genus Aceria (Acari: Eriophyidae) from south India. J. Acarol., 12 (1\&2): 15-88.

Salari, A.; Lotfollahi, P.; Mehrvar, A. and Houshyari, F. 2018. One new Aculops species (Trombidiformes: Eriophyoidea) from Ziziphus jujuba Mill. (Rhamnaceae) in Iran. Biologia, 73(2): 145-149.

Navia, D.; Ochoa, R.; Welbourn, $\mathrm{C}$ and Ferragut, F. 2010. Adventive eriophyoid mites: a global review of their impact, pathways, prevention and challenges. Exp. Appl. Acarol., 51:225-255.

Wilson, N.S. and Oldfield, G.N. 1966. New species of eriophyid mites from Western North America with a discussion of eriophyid mites on Populus. Ann. Entom.l Soc. America, 59 (3): 585-599.

Zaher, M.A. 1984. Survey and ecological studies on phytophagous, predaceous and soil mites in Egypt. 1. Phytophagous mites in Egypt (Nile Valley and Delta). PI 480 Programme U.S.A., Project No. EG-ARS-30, Grant No. FG-Eg-139, 228 pp. 